\title{
Evaluation of umbilical cord mesenchymal stem cell labeling with superparamagnetic iron oxide nanoparticles coated with dextran and complexed with Poly-L-lysine
}

\author{
Avaliação da marcação de células-tronco mesenquimais de cordão umbilical \\ com nanopartículas superparamagnéticas de óxido de ferro recobertas \\ com Dextran e complexadas a Poli-L-Lisina
}

\author{
Tatiana Taís Sibov ${ }^{1}$, Liza Aya Mabuchi Miyaki², Javier Bustamante Mamani ${ }^{1}$, Luciana Cavalheiro Marti \\ Luiz Roberto Sardinha ${ }^{3}$, Lorena Favaro Pavon ${ }^{1}$, Daniela Mara de Oliveira ${ }^{4}$, \\ Walter Humberto Cardenas ${ }^{1}$, Lionel Fernel Gamarra ${ }^{1}$
}

\begin{abstract}
Objective: The objective of this study was to evaluate the effect of the labeling of umbilical cord vein derived mesenchymal stem cells with superparamagnetic iron oxide nanoparticles coated with dextran and complexed to a non-viral transfector agent transfector poly-L-lysine. Methods: The labeling of mesenchymal stem cells was performed using the superparamagnetic iron oxide nanoparticles/dextran complexed and not complexed to poly-L-lysine. Superparamagnetic iron oxide nanoparticles/dextran was incubated with poly-L-lysine in an ultrasonic sonicator at $37^{\circ} \mathrm{C}$ for 10 minutes for complex formation superparamagnetic iron oxide nanoparticles/dextran/poly-L-lysine by electrostatic interaction. Then, the mesenchymal stem cells were incubated overnight with the complex superparamagnetic iron oxide nanoparticles/dextran/poly-L-lysine and superparamagnetic iron oxide nanoparticles/dextran. After the incubation period the mesenchymal stem cells were evaluated by internalization of the complex superparamagnetic iron oxide nanoparticles/dextran/polyL-lysine and superparamagnetic iron oxide nanoparticles/dextran by Prussian Blue stain. Cellular viability of labeled mesenchymal stem cells was evaluated by cellular proliferation assay using 5,6-carboxyfluorescein-succinimidyl ester method and apoptosis detection by Annexin V- Propidium lodide assay. Results: mesenchymal stem cells labeled with superparamagnetic iron oxide nanoparticles/ dextran without poly-L-lysine not internalized efficiently the superparamagnetic iron oxide nanoparticles due to its low presence detected within cells. Mesenchymal stem cells labeled with the
\end{abstract}

complex superparamagnetic iron oxide nanoparticles/dextran/polyL-Iysine efficiently internalized the superparamagnetic iron oxide nanoparticles due to greater presence in the cells interior. The viability and apoptosis assays demonstrated that the mesenchymal stem cells labeled and not labeled respectively with the superparamagnetic iron oxide nanoparticles/dextran/poly-L-lysine continue to proliferate over seven days and the percentage of cells in early or late apoptosis is low compared to the percentage of live cells over the three days. Conclusion: Our results showed that the use of poly-L-lysine complexed with superparamagnetic iron oxide nanoparticles/dextran provides better internalization of these superparamagnetic iron oxide nanoparticles in mesenchymal stem cells Thus, we demonstrated that this type of labeling is not cytotoxic to the mesenchymal stem cells, since the viability and apoptosis assays showed that the cells remain alive and proliferating. The efficiency of this type of labeling in mesenchymal stem cells can provide non-invasive methods for monitoring these cells in vivo.

Keywords: Mesenchymal stem cells; Magnetite nanoparticles; PolyL-Lysine; Umbilical veins

\section{RESUMO}

Objetivo: 0 objetivo deste estudo foi avaliar 0 efeito da marcação de células-tronco mesenquimais obtidas da parede da veia do cordão umbilical com nanopartículas de óxido de ferro superparamagnéticas

\footnotetext{
Study carried out at Instituto Israelita de Ensino e Pesquisa Albert Einstein, Hospital Israelita Albert Einstein - HIAE, São Paulo (SP), Brazil.

${ }^{1}$ Instituto do Cérebro - InCe, Hospital Israelita Albert Einstein - HIAE, São Paulo (SP), Brazil.

${ }^{2}$ Instituto do Cérebro - InCe, Hospital Israelita Albert Einstein - HIAE, São Paulo (SP), Brazil; Faculdade de Enfermagem, Hospital Israelita Albert Einstein - HIAE, São Paulo (SP), Brazil.

${ }^{3}$ Centro de Pesquisa Experimental, Hospital Israelita Albert Einstein - HIAE, São Paulo (SP), Brazil.

${ }^{4}$ Universidade de Brasília - UnB, Brasilia (DF), Brazil.

Corresponding author: Tatiana Taís Sibov - Avenida Albert Einstein, 627 - $2^{\circ}$ subsolo - Instituto do Cérebro (InCe) - Zip code: 05651 -901 - São Paulo (SP), Brazil - Phone.: (55 11) 2151-2044 -

E-mail: tatianats@einstein.br

Received on: Sep 7, 2011 - Accepted on: Jun 6, 2012

Conflict of interest: none.
} 
recobertas com dextran e complexadas a um agente transfector não viral denominado de Poli-L-Lisina. Métodos: A marcação das células-tronco mesenquimais foi realizada utilizando as nanopartículas de óxido de ferro superparamagnéticas recobertas com dextran complexadas e não complexadas a Poli-L-Lisina. As nanopartículas de óxido de ferro superparamagnéticas recobertas com dextran foram incubadas com o Poli-L-Lisina em um sonicador ultrassonico a $37^{\circ} \mathrm{C}$ por 10 minutos, para a formação do complexo através de interação eletrostática. Em seguida, as células-tronco mesenquimais foram incubadas overnight com as nanopartículas de óxido de ferro superparamagnéticas complexadas e não com Poli-L-Lisina. Após o período de incubação as células-tronco mesenquimais foram avaliadas quanto à internalização do complexo nanopartícula de óxido de ferro superparamagnéticas /dextran/Poli-L-Lisina e nanopartícula de óxido de ferro superparamagnéticas /dextran através de ensaio citoquímico com azul de prússia. A viabilidade celular das célulastronco mesenquimais marcadas foi avaliada através do ensaio de proliferação celular utilizando o método de 5,6-carboxy-fluoresceinsuccinimidyl-ester e de morte celular através do método de anexinaiodeto de propídeo, ambos utilizando o recurso de citometria de fluxo. Resultados: Observamos nos ensaios citoquímicos que as célulastronco mesenquimais que foram marcadas com as nanopartícula de óxido de ferro superparamagnéticas /dextran sem a Poli-L-Lisina, não internalizaram com eficiência as nanopartículas devido pouca detecção de sua presença no interior das células. As células-tronco mesenquimais marcadas com o complexo nanopartícula de óxido de ferro superparamagnéticas /dextran/Poli-L-Lisina internalizaram com eficiência as nanopartículas devido à maior presença destas no interior das células. Os ensaios de viabilidade e morte celular demonstraram respectivamente que as células-tronco mesenquimais marcadas com as nanopartícula de óxido de ferro superparamagnéticas /dextran/PoliL-Lisina continuam proliferando ao longo de sete dias e a porcentagem de células em apoptose inicial e tardia é baixa em relação à porcentagem de células vivas ao longo de três dias. Conclusão: Evidenciamos através de nossos resultados a necessidade da utilização da Poli-L-Lisina complexada com a nanopartícula de óxido de ferro superparamagnéticas /dextran para melhor internalização nas célulastronco mesenquimais. Paralelamente, demonstramos que este tipo de marcação não é citotóxico para as células-tronco mesenquimais já que os testes de morte e viabilidade celular mostraram que as células continuam vivas e proliferando.

Descritores: Células-tronco mesenquimais; Nanopartículas de magnetita; Poli-L-Lisina; Veias umbilicais

\section{INTRODUCTION}

Superparamagnetic iron oxide nanoparticles (SPIONs) have been widely used in various biomedical applications in vitro and in vivo ${ }^{(1,2)}$. In these applications, there is the need for high specificity, efficiency and quick internalization of the SPION into specific target cells, but this may be limited by various factors $^{(3)}$ : (i) aggregation of SPIONs (SPIONs have a high surface/volume ratio, and thus, tend to agglomerate); (ii) short half-life of SPIONs in blood circulation (when the SPIONs agglomerate, or adsorb plasma proteins, which are rapidly eliminated from the blood circulation by macrophages from the phagocyte mononuclear system before they can reach the target cells); (iii) and the low efficiency of intracellular capture of SPIONs.

Biocompatible polymers and agents with specific targets are, therefore, bound to the surface of SPIONs to avoid agglomeration and to increase its nonspecific intracellular absorption ${ }^{(4,5)}$.

All the applications require that the SPIONs have high magnetization values and a size smaller than $100 \mathrm{~nm}$, with a narrow distribution among the sizes, in order to present uniform physical and chemical properties $^{(6)}$. The nature of the surface covering of SPIONs helps in the determination of the total size of the colloid, and also plays a significant role in the biokinetics and biodistribution of SPIONs in vivo ${ }^{(1,2)}$.

From the beginning of the use of contrast agents in magnetic resonance (1987), most of the superparamagnetic iron oxides (SPIONs) and ultrasmall superparamagnetic iron oxides (USPION) have been absorbed by macrophages, and these particles may be coated by dextran or other types of polymer coatings in order to attain good dispersion in water and selectivity ${ }^{(7)}$. Dextran (DX)-coated SPIONs (DX), however, are not captured efficiently by cells, probably due to aggregation and to the size of the SPION-DX, which can cause inefficient cell endocytosis. The nonefficient capture of SPION-DX has been reduced by coating these SPIONs with polymers ${ }^{(2)}$.

Cationic compounds, such as Poly-L-Lysine (PLL) ${ }^{(8)}$ have been used to help in the interaction between the SPION and the surface of the cells that present with negative charges, and consequently endosomal absorption $^{(2,8)}$. PLL is a cationic polymer that presents with high density of positive changes in its chain, which leads to an attraction and consequent bond to molecules with predominantly negative charges ${ }^{(8)}$.

MSC are multipotent cells that have the capacity to originate other types of cells to a limited extent, for example, adipocyte, osteoblast and chondrocyte cells ${ }^{(9,10)}$. Transplantation of this cellular type could be an effective treatment for diseases such as ischemic cerebrovascular accidents (ICVA) and spinal cord lesions. Nonetheless, accompaniment of the behavior of these cells in vivo is still one of the obstacles to its use in cell therapy. The possibility of an efficient form of labeling of these cells with SPIONs, without cytotoxic effects and loss of viability, could make available noninvasive methods for the follow-up of these cells in vivo. 
In this way, labeling MSC with SPIONs has been studied over the last years ${ }^{(11,12)}$, but there are still no studies that completely characterize the cytotoxic effects of this type of labeling on cellular proliferation, survival and differentiation.

Thus, in this study we will compare the efficiency of MSC labeling using SPION-DX, complexed or not with PLL, with the intention of analyzing the ease of incorporation of the particle by the cells and the cytotoxicity of this type of labeling. Therefore we will analyze cellular viability over the course of seven days of labeling and cellular death over the course of three days. Our results have demonstrated that MSCs are labeled with the SPION-DXs in an efficient manner, and do not cause toxic effects to the cells under study.

\section{OBJECTIVE}

To compare the efficiency of internalization of SPION-DX complexed or not with PLL by the MSC. To evaluate if the internalization of SPION-DX-PLL causes cytotoxicity to the MSC using flow cytometry techniques.

\section{METHODS}

\section{Umbilical cord sample collection}

Five samples of umbilical cord were collected after signing of the informed consent form by the mother (donor) as per the Ethics in Research Committee (CEP - No. 1059) of the Instituto Israelita de Ensino e Pesquisa Albert Einstein (São Paulo, Brazil). These samples were collected by sectioning of the umbilical cord at the time of delivery and preserved in Phosphate Buffered Saline 1x (PBS, Sigma-Aldrich) with 100mM of EDTA anticoagulant, and were processed soon afterwards or within up to 12 hours after the collection.

\section{Umbilical cord sample processing}

After two washings with PBS 1x (Sigma-Aldrich) of the umbilical cord, the MSCs were removed from the sample by enzymatic digestion using Collagenase Type I (Sigma-Aldrich) for 30 minutes, $37^{\circ} \mathrm{C}$ in $5 \% \mathrm{CO}^{2}$. Next, the enzyme was inactivated with Fetal Bovine Serum (GIBCO/Invitrogen Corporation).

\section{MSC culture}

The MSCs isolated from the umbilical cord were transferred to $25-\mathrm{cm}^{2}$ plates at a cellular density of $10^{7}$ cells $/ \mathrm{cm}^{2}$ containing Dulbecco's Modified Eagle's-Low Glucose medium (DMEM-LG, GIBCO Invitrogen Corporation) supplemented with L-Glutamine $200 \mathrm{mM}$, Antibiotic-Antimycotic 10,000U/mL sodium penicillin, $10,000 \mu \mathrm{g} / \mathrm{mL}$ streptomycin sulfate, $25 \mu \mathrm{g} / \mathrm{mL}$ amphotericin B (GIBCO/Invitrogen Corporation) and $10 \%$ Fetal Bovine Serum (GIBCO/Invitrogen Corporation). The MSC cultures were maintained at $37^{\circ} \mathrm{C}$ in $5 \% \mathrm{CO}_{2}$ and the non-adherent cells were removed from the culture plate after 24 hours. The culture medium was changed on alternate days. The experiments were performed at the fourth cellular passage with the $90 \%$ confluent cells.

\section{Immunophenotyping of MSC by flow cytometry}

The MSC characterization experiment performed by flow cytometry used commercially available monoclonal antibodies. The labeling technique used was compliant with the manufacturer's techniques. Briefly, the cells were labeled with the selected monoclonal antibodies and incubated in the dark for 30 minutes at room temperature; after incubation the cells were washed and fixed in $1 \%$ paraformaldehyde. The monoclonal antibodies used were: CD14 FITC clone:M5E2 (BD Pharmingen, San Diego, CA), CD29 PE clone:MAR4 (BD Pharmingen, San Diego, CA), CD31 PE clone:WM59 (BD Pharmingen, San Diego, CA), CD45 PerCP CY5.5 clone:2D1 (BD Biosciences, San Jose, CA), CD73 PE clone:AD2 (BD Pharmingen, San Diego, CA), CD105 PE clone:43A3 (Biolegend, San Diego, CA), CD90 APC clone:5E10 (BD Pharmingen, San Diego, CA), HLA-A,B and C FITC clone:G46-2.6 (BD Pharmingen, San Diego, CA, CD106 FITC clone:51-10C9 (BD Pharmingen, San Diego, CA), CD133 APC clone:293C3 (Myltenyi Biotec, Germany) and the related control isotopes. Data acquisition was performed on the FACSARIA flow cytometry equipment (BD Biosciences, San Jose, CA) and the results were analyzed using FACSDIVA (BD Biosciences) and FLOWJO software (Tree Star, Ashland, OR).

\section{Dextran-coated iron oxide nanoparticles}

Dextran-coated SPIONs in aqueous dispersion (fluidMAG-DX) were acquired from Chemicell; the ferrofluid has a concentration of $50 \mathrm{mg} / \mathrm{mL}$, with a crystalline phase magnetic core identified as magnemite $\left(\mathrm{g}-\mathrm{Fe}_{2} \mathrm{O}_{3}\right)$, a hydrodynamic size of $50 \mathrm{~nm}$, number of particles $\sim 1.3 \times 10^{16} / \mathrm{g}$, density $\sim 1.25 \mathrm{~g} / \mathrm{cm}^{3}$, functional group Hydroxyl and matrix of dextran. 


\section{Labeling MSC with SPION-Dextran-PLL}

The SPION-DX $(500 \mu \mathrm{g} / \mathrm{mL})$ and the PLL $(1.5 \mu \mathrm{g} / \mathrm{mL})$ were incubated at $37^{\circ} \mathrm{C}$ for 10 minutes in the ultrasound sonicator (Transonic T460/H - Elma). Next, the experiment of MSC labeling with the SPION-DXPLL complex was performed in a 24-well plate, at a concentration of $500 \mu \mathrm{g} / \mathrm{mL}$ of SPION-DX-PLL, for a cellular concentration of approximately $10^{5}$. MSC labeling with the SPION-DX-PLL complex was performed in RPMI medium (GIBCO Invitrogen Corporation) and 10\% Fetal Bovine Serum (GIBCO/ Invitrogen Corporation), during an overnight incubation period, maintained at $37^{\circ} \mathrm{C}$ in $5 \% \mathrm{CO}_{2}$.

\section{Internalization analysis of SPION-DX-PLL in the MSC}

The labeled MSCs were washed with PBS 1x (SigmaAldrich) for the removal of excess particles, and then fixed with $4 \%$ paraformaldehyde. Next the cytochemical assay was carried out with 5\% Prussian Blue - 5\% Potassium Ferrocyanide Solution (Sigma-Aldrich) / 5\% Solution of $\mathrm{HCl} 37 \%$ (Merck, Germany), to verify the internalization of the particles in the MSC. The analysis was performed on a Fluorescence Microscopy microscope (IX51 Olympus).

\section{Cellular proliferation assay - CFSE}

For analysis of proliferation, $10^{5}$ MSC from each sample were resuspended in PBS 1x (Sigma-Aldrich) containing $1 \mu \mathrm{M}$ of CFSE (5,6-carboxy-fluoresceinsuccinimidyl-ester, Molecular Probes) and incubated at $37^{\circ} \mathrm{C}$ during 10 minutes; after this period, $9 \mathrm{~mL}$ of PBS 1x (Sigma-Aldrich) - 1\% Fetal Bovine Serum (GIBCO/Invitrogen Corporation) were added, the cells were centrifuged at $400 \mathrm{~g}$ during 10 minutes; the supernatant was discarded, and the cells were then resuspended in $10 \mathrm{~mL}$ of PBS $1 \mathrm{x}$ (Sigma-Aldrich) - 1\% Fetal Bovine Serum (GIBCO/Invitrogen Corporation) and incubated at $37^{\circ} \mathrm{C}$ during 15 minutes. Following this period, the cells were again centrifuged at $400 \mathrm{~g}$ during 10 minutes and resuspended in PBS 1x (SigmaAldrich) - 1\% Fetal Bovine Serum (GIBCO/Invitrogen Corporation). The assay was performed in 24, 72 hours and 7 days. Data acquisition was performed on FACSARIA flow cytometry equipment (BD Biosciences, San Jose, CA).

\section{Cellular death assay - annexin/propidium iodide}

For the cellular death assay, the BD Pharmingen FITC Annexin V Apoptosis Detection Kit I (BD
Biosciences, San Diego, CA) was used. An amount of $10^{5}$ MSC from each sample was resuspended in $200 \mathrm{uL}$ of Binding Buffer 1x and then centrifuged at $400 \mathrm{~g}$ during 5 minutes at $4^{\circ} \mathrm{C}$. After centrifugation, the supernatant was removed and the cells were once again resuspended in $200 \mathrm{uL}$ of Binding Buffer $1 \mathrm{x}$ and centrifuged at $400 \mathrm{~g}$ during 5 minutes at $4^{\circ} \mathrm{C}$ - then the supernatant was removed and the cells were resuspended in the MIX (Binding Buffer 1x/Annexin/ propidium iodide) and incubated in the dark for 15 minutes - posteriorly, 100uL of Binding Buffer $1 \mathrm{x}$ were added. Data acquisition was performed within one hour of labeling in the FACSARIA flow cytometry equipment (BD Biosciences, San Jose, CA). Programmed cellular death or early apoptosis has as marker the exposure of phosphatidylserine (FS) on the cell membrane, which binds by affinity with annexin V. In late programed cellular death or late apoptosis, besides FS exposure on the cell membrane, pores appear on the membrane making it pervious to propidium iodide, which gives the cells double labeling (annexin-IP). In case of cellular necrosis, the cell membrane becomes permeable with the consequent labeling by propidium iodide, and there is no externalization of FS, but due to the formation of pores on the membrane, there may also be internalization of annexin V. In this case, it is not possible to differentiate the process of late apoptosis from the process of necrosis.

\section{RESULTS}

\section{Characterization of MSC isolated from umbilical cord by flow cytometry}

The MSCs isolated from umbilical cord samples presented with fibroblastic morphology and reached an 80 to $90 \%$ confluence in seven days of culture (Figure 1). In the immunophenotyping assay performed by flow cytometry, the MSCs did not express positivity for CD14, CD31, CD34, CD45, CD106, CD133 and

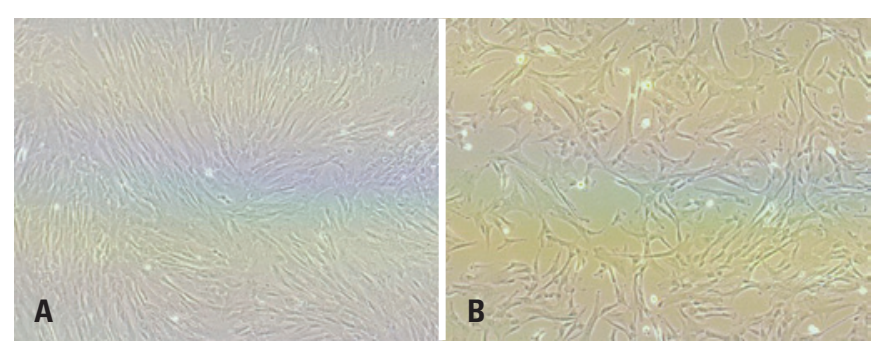

Figure 1. Mesenchymal stem-cells isolated from samples of umbilical cord. A) MSC culture with approximately $90 \%$ of confluence $-400 x$; B) MSC culture with approximately $80 \%$ of confluence 
HLA-DR. The results are presented as histograms, which on their $\mathrm{x}$ axis show the intensity of fluorescence for each specific antibody. The MSCs expressed positivity for HLA A, B and C (HLA-I), CD29, CD73, CD90 and CD105; the results are represented by histograms and the cell populations are labeled positively; the cells labeled with control isotopes are superimposed on the same graph (Figure 2).
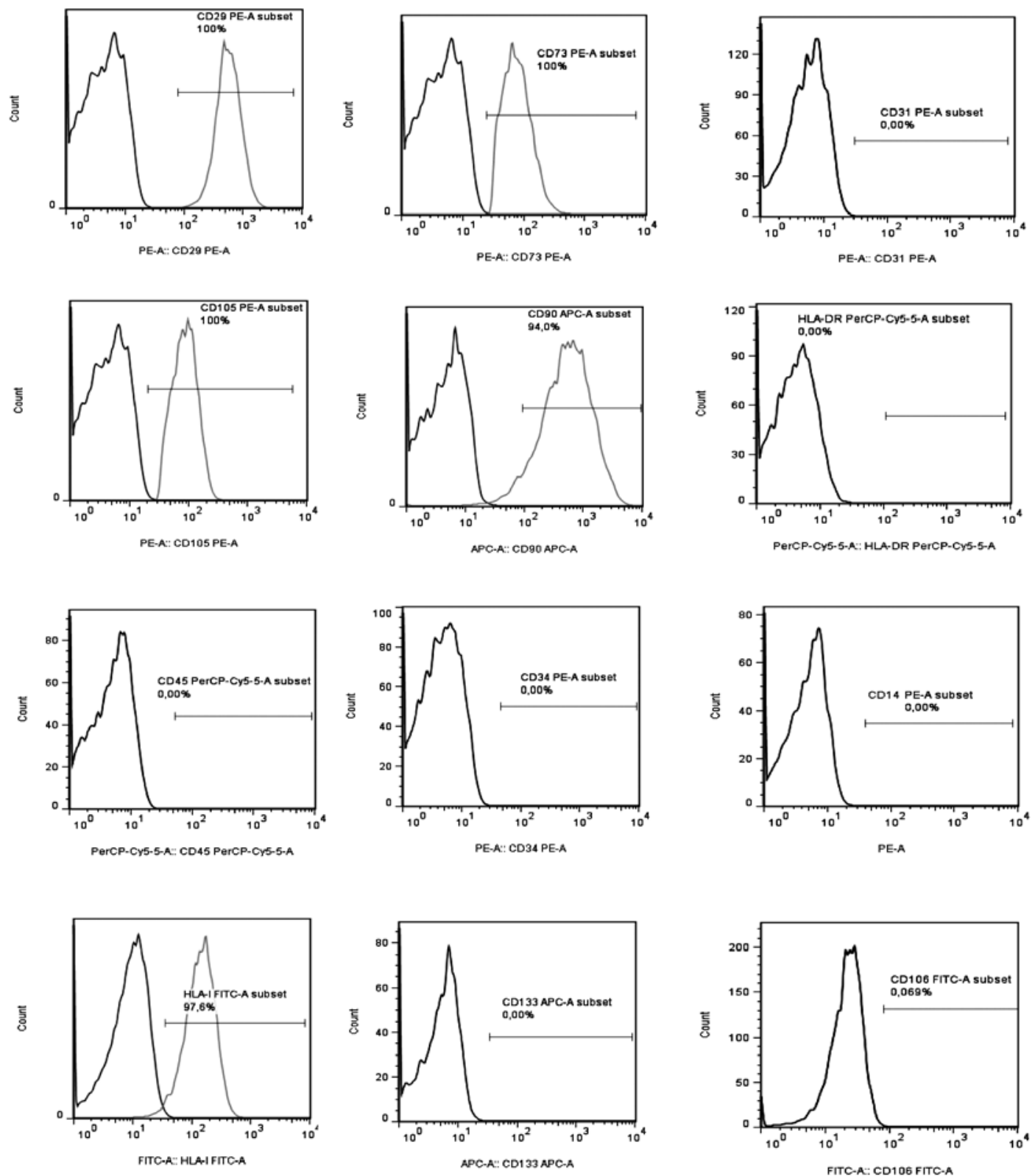

Figure 2. Immunophenotyping of the MSC isolated from umbilical cord. The first graph represents by points all the cells acquired, which are visualized by two parameters, on the $x$ axis the parameter that represents size (FSC) and on the y axis the parameter that represents granularity (SSC), the cells selected on this graph were analyzed in all subsequent graphs 


\section{MSC labeled with the SPION-DX-PLL complex}

Labeling of the MSC with the SPION-DX with and without PLL was analyzed after performance of the cytochemical assay with Prussian Blue. Under these conditions, internalization of the SPION-DX was observed only when PLL was complexed with the particle as a non-viral transfector agent (Figure $3 \mathrm{~A}$, $\mathrm{B}, \mathrm{C})$. Thus, blue labels located intracellularly were detected when the SPION-DX were complexed with PLL, relative to the negative control - non-labeled MSC (Figure 3F). In the MSCs labeled only with the SPION-DX, only a few small blue intracellular precipitates were noted, demonstrating less efficiency in labeling (Figure $3 \mathrm{D}, \mathrm{E}$ ).

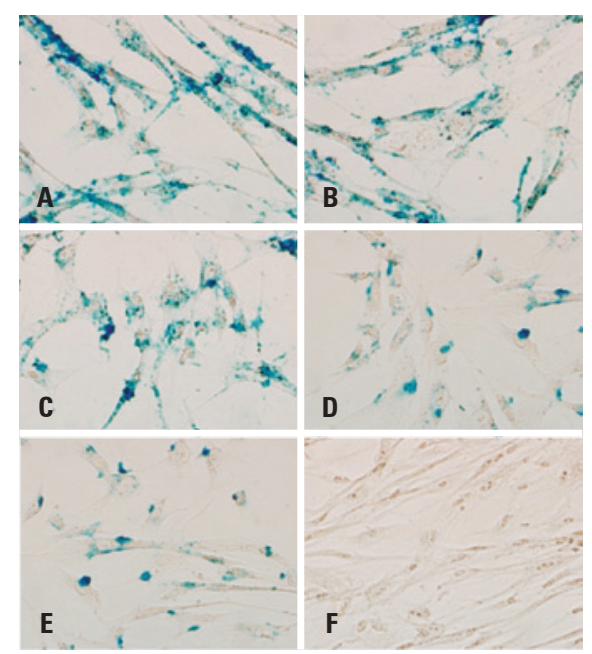

Figure 3. MSCs labeled with the complex, SPION-DX-PLL. (A, B, C) MSCs labeled with the complex, SPION-DX-PLL, 600x; (D, E) MSCs labeled with the SPION-DX without PLL, 400x; (F) MSCs not labeled - negative control

\section{Proliferation of MSC labeled with SPION-DX-PLL}

CFSE is a vital dye with fluorescent properties used to indirectly estimate cellular proliferation: one cell labeled with CFSE when dividing generates two daughter cells, which contain half of the quantity of the original cell CFSE; therefore, the fluorescence of the daughter cells will be half the fluorescence of the mother cell.

The results of this test showed proliferative activity in MSCs labeled with the SPION-DX-PLL over the seven days. During this period, it was possible to detect successive cell divisions, and consequently, dilution of CFSE inside the cells. The proliferation detected by the dilution of the CFSE in the cells labeled with SPION-DX-PLL was close to the values detected in the non-labeled cells (negative control), indicating that SPION-DX-PLL does not interfere in the proliferative activity of the MSCs (Figure 4).

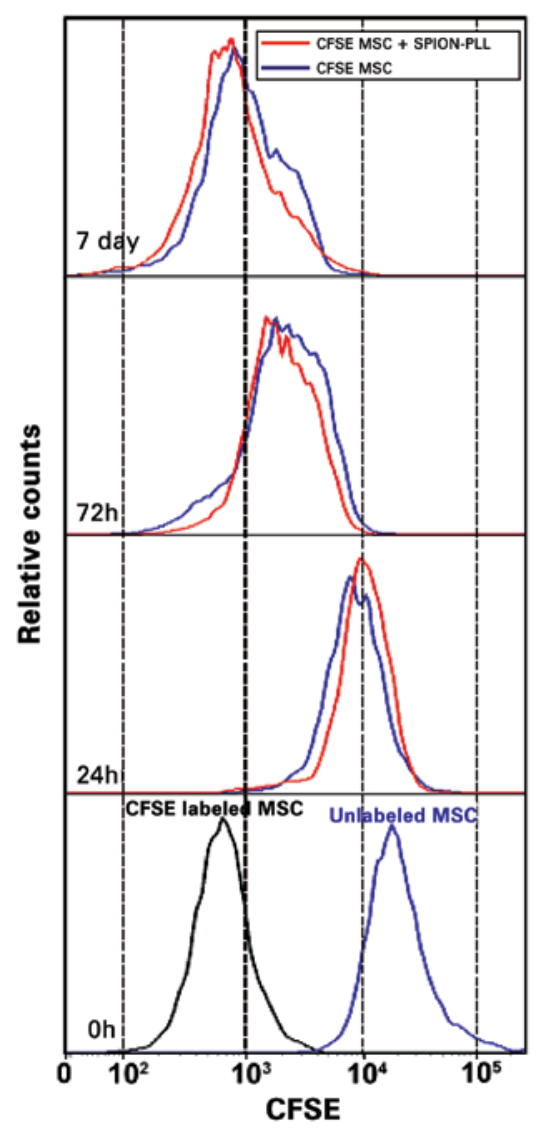

Figure 4. Cellular proliferation assay by the CFSE method. As the curve is dislocated to the left, it means the MSCs are proliferating. We observed that over 7 days, the MSCs labeled with the SPION-DX-PLL (red curve) dislocated along with the control MSCs (not labeled - blue curve)

\section{Viability of MSC labeled with SPION-DX-PLL}

The MSCs labeled with SPION-DX-PLL were evaluated as to programed cellular death or apoptosis; early apoptosis has as mark the exposure of phosphatidylserine (FS) on the cell membrane, which binds by affinity to annexin $\mathrm{V}$.

The MSCs were also evaluated as to late programed cellular death or late apoptosis, in which in addition to the exposure of FS on the cellular membrane, there is also the appearance of pores on the membrane, making it pervious to propidium iodide, which in turn makes the cell doubly labeled (annexin-IP). In case of cellular necrosis, there is permeabilization of the cell membrane with the consequent labeling by propidium iodide, and no externalization of FS, although due to the formation of pores on the membrane, there may also be internalization of annexin V, in which case, it is not possible to differentiate the process of late apoptosis from the process of necrosis. The results showed the viability of the MSCs labeled with the SPION-DX-PLL over the period of three days, which is detected due to the relationship between the number of live cells and the number of dead cells, 
whether due to early/late apoptosis or necrosis - Q3, Q2, Q1 respectively (Figure $5 \mathrm{C}, \mathrm{F}, \mathrm{I}$ ), relative to the non-labeled cells - negative control (Figure 5. B, E, $\mathrm{H})$. Over the period of 72 hours of assay, we noticed a low index of cellular death in MSCs labeled with the SPION-DX-PLL, especially due to late apoptosis/ necrosis relative to the non-labeled MSCs (negative control) (Figure 5 C, F, I and B, E, H, respectively).
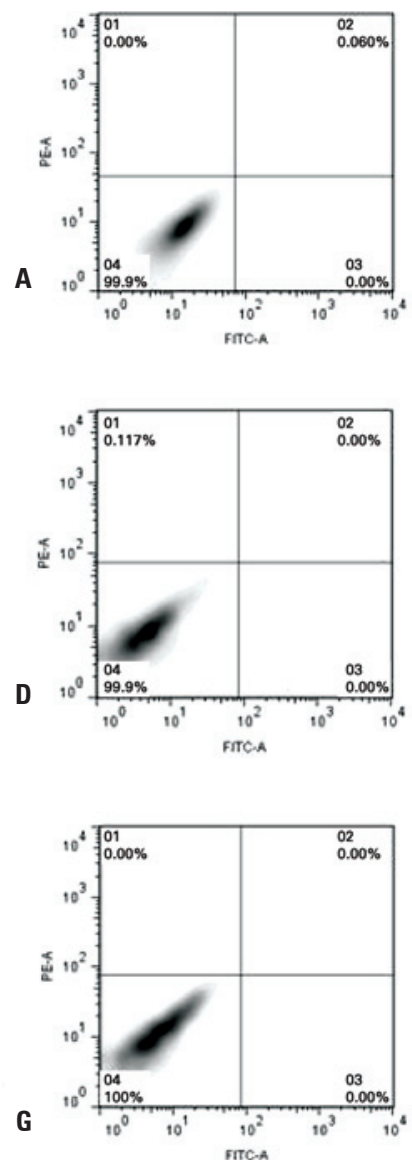
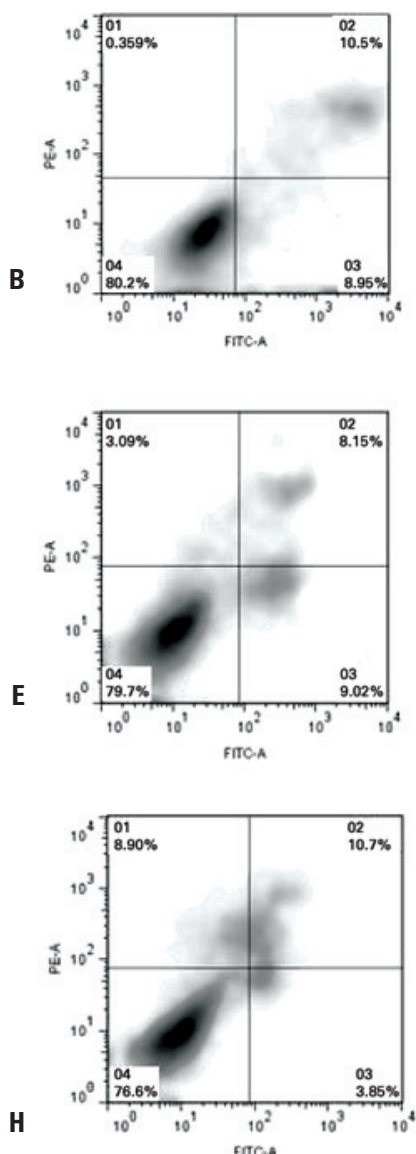
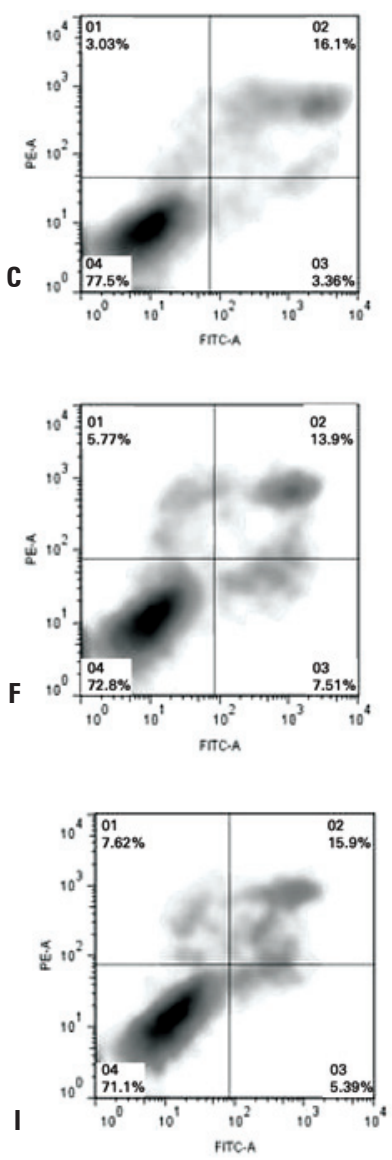

Figure 5. Cellular viability assay by the annexin-propidium iodide method. (A, D, G) Represent the MSCs not labeled with the SPION-DX-PLL (negative control) and not labeled for annexin-propidium iodide (in-house negative control of the viability assay) relative to 24,48 and 72 hours, respectively. (B, E, H) Represent the MSCs not labeled with the SPION-DX-PLL (negative control) and labeled with annexin-propidium iodide (in-house positive control of the viability assay) relative to 24,48 and 72 hours, respectively. (C, F, I) Represent the MSCs labeled with the SPION-DX-PLL and labeled with annexin-propidium iodide relative to 24,48 and 72 hours, respectively

\section{DISCUSSION}

The great advantage of the technique of labeling MSC with the SPION-DX-PLL is the incorporation of this complex by the cells without great alterations in viability and capacity for cellular proliferation, besides the fact that labeling occurs in an efficient manner.

PLL is a cationic polymer (presence of $\mathrm{NH} 2$ groups) that presents with a high density of positive charges in its chain, which leads to an attraction and consequent binding to molecules with negative charges ${ }^{(13,14)}$. Thus, it is used as a non-viral transfector agent promoting cellular adhesion by electrostatic interaction due to its positive charge while the cell surface presents with negative charges. PLL is known for adsorbing proteins not only from solutions with nutrients of culture media, but also proteins present in the cell membrane ${ }^{(15)}$.

In this way, the principle of labeling is the combination of highly charged macromolecules with the surface composed of opposing charges, resulting in the formation of a SPION-DX-PLL complex that facilitates interactions and consequent endocytosis and/or incorporation of the particles into cellular endosomes ${ }^{(13)}$. The assays performed with the SPIONDX non-complexed with PLL show a less efficient labeling, with less incorporation of particles by the cells (Figure 3). In this way, the use of PLL as a non-viral transfector agent for cellular labeling with nanoparticles is very favorable due to its efficiency, followed by the high reproducibility of the assays 
and low cost. Nevertheless, the use of PLL in high concentrations may cause a disadvantage in terms of particle aggregation outside of the cells ${ }^{(14,15)}$. Thus, with PLL at a $1.5 \mathrm{ug} / \mathrm{mL}$ concentration used in our assays, we were able to standardize adequate conditions for obtaining efficiency in internalization of nanoparticles by the MSCs, with no cytotoxic effects and without their aggregation.

As to cell viability of labeled MSCs, an estimate of this type of labeling was shown by means of the annexin-propidium iodide assay. We opted for this type of assay, since we were able to distinguish between live cells, in early and late apoptosis and necrosis. We noted a slight increase, although with no significance, in the number of cells in late apoptosis/necrosis 72 hours after labeling of MSC relative to 24 and 48 hours after labeling (Figure 5). Data in literature show that cells labeled with high concentrations of nanoparticles and PLL result in an increased percentage of cellular death when compared to control cells ${ }^{(16,17)}$.

Despite the concentration of nanoparticles used in the assays being $500 \mathrm{ug} / \mathrm{mL}$, which is a high concentration relative to other data in literature, it demonstrated that there was no cytotoxic effect for the MSCs labeled with the SPION-DX-PLL. Therefore, our standardized protocol labeling MSCs with the SPION-DX-PLL seems viable for the type of analysis proposed.

In the same way, we evaluated the effects of labeling on the proliferative activity of the labeled MSCs by means of the CFSE assay. We demonstrated that MSC labeled with the nanoparticles incubated over the extent of seven days maintained their proliferative activity. However, due to successive cell divisions and consequent dilution of the CFSE inside the cells, the fluorescence of the labeled cells reached the values of non-labeled cells (negative control). Thus, we noted that the values of fluorescence of the MSCs labeled with the SPION-DX-PLL did not differ from the values found in the control MSCs, indicating that the SPIONDX-PLL do not interfere in the proliferative activity of the MSCs (Figure 4).

In this way, this study generated preliminary results of fundamental importance, since we were able to standardize an efficient label of the MSCs with SPIONDX-PLL and demonstrate the absence of cytotoxicity, as per the observations that the labeled cells remained viable and proliferative.

This type of study is promising for the future development of monitoring techniques in vivo of temporal and spatial migration of labeled cells to tissues of interest, thus emphasizing the development of strategies for the repair or substitution of tissues and new therapies.

\section{CONCLUSION}

This study showed that is it possible to standardize efficient labeling with SPION-DX-PLL and with an absence of cytotoxicity for the MSC, thus making possible the performance of studies of migration and homing in vivo, improving the perception of migration, location and actions of these cells in face of tissue damage.

\section{REFERENCES}

1. Pankhurst QA, Connolly J, Jones SK, Dobson J. Applications of magnetic nanoparticles in biomedicine. J Phys D Appl Phys. 2003;36:R167-R181.

2. Babic M, Horák D, Trchová M, Jendelová P, Glogarová K, Lesný P, et al. Poly(Llysine)-modified iron oxide nanoparticles for stem cell labeling. Bioconjug Chem. 2008;19(3):740-50.

3. Stella B, Arpicco S, Peracchia MT, Desmaële D, Hoebeke J, Renoir M, et al. Design of folic acid-conjugated nanoparticles for drug targeting. J Pharm Sci. 2000;89(11):1452-64.

4. Zhang Y, Zhang J. Surface modification of monodisperse magnetite nanoparticle for improved intracellular uptake to breast cancer cells. J Colloid Interface Sci. 2005;283(2):352-7.

5. Allen MJ, MacRenaris KW, Venktasubramanian PN, Meade TJ. Cellular delivery of MRI contrast agents. Chem Biol. 2004;11(3):301-7.

6. Stark DD, Weissleder R, Elizondo G, Hahn PF, Saini S, Todd LE, et al. Superparamagnetic iron oxide: clinical application as a contrast agent for MR imaging of the liver. Radiology. 1988;168(2):297-301.

7. Molday RS, MacKenzie D. Immunospecific ferromagnetic iron-dextran reagents for the labeling and magnetic separation of cells. J Immunol Methods. 1982; 52(3):353-67.

8. Arbab AS, Bashaw LA, Miller BR, Jordan EK, Lewis BK, Kalish H, et al. Characterization of biophysical and metabolic properties of cells labeled with superparamagnetic iron oxide nanoparticles and transfection agent for cellular MR imaging. Radiology. 2003;229(3):838-46.

9. Arbab AS, Yocum GT, Wilson LB, Parwana A, Jordan EK, Kalish $H$, et al. Comparison of transfection agents in forming complexes with ferumoxides, cell labeling efficiency, and cellular viability. Mol Imaging. 2004;3(1):24-32.

10. Kalish H, Arbab AS, Miller BR, Lewis BK, Zywicke HA, Bulte JW, et al Combination of transfection agents and magnetic resonance contrast agents for cellular imaging: relationship between relaxivities, electrostatic forces, and chemical composition. Magn Reson Med. 2003;50(2):275-82

11. Can $A$, Balci D. Isolation, culture, and characterization of human umbilical cord stroma-derived mesenchymal stem cells. Methods Mol Biol. 2011;698:51-62.

12. Kiessling $A A$, Anderson $S$. Human embryonic stem cells: an introduction to the science and therapeutic potential. Sudbury (MA): Jones \& Bartlett Publishers; 2003.

13. Arbab AS, Bashaw LA, Miller BR, Jordan EK, Bulte JW, Frank JA Intracytoplasmic tagging of cells with ferumoxides and transfection agent for cellular magnetic resonance imaging after cell transplantation: methods and techniques. Transplantation. 2003;76(7):1123-30.

14. Mailänder V, Landfester $\mathrm{K}$. Interaction of nanoparticles with cells. Biomacromolecules. 2009;10(9):2379-400.

15. Montet-Abou K, Montet X, Weissleder R, Josephson L. Transfection agent induced nanoparticle cell loading. Mol Imaging. 2005;4(3):165-71.

16. Arbab AS, Bashaw LA, Miller BR, Jordan EK, Lewis BK, Kalish $H$, et al Characterization of biophysical and metabolic properties of cells labeled 
with superparamagnetic iron oxide nanoparticles and transfection agent for cellular MR imaging. Radiology. 229(3):838-46. Comments in: Radiology. 2003;229(3):615-6.
17. Omidkhoda A, Mozdarani H, Movasaghpoor A, Fatholah AA. Study of apoptosis in labeled mesenchymal stem cells with superparamagnetic iron oxide using neutral comet assay. Toxicology in Vitro. 2007;21(6):1191-6. 